\title{
YIELD OF FERTIGATED BELL PEPPER UNDER DIFFERENT SOIL WATER TENSIONS AND NITROGEN FERTILIZATION ${ }^{1}$
}

\author{
HELANE CRISTINA AGUIAR SANTOS ${ }^{2}$, JOAQUIM ALVES DE LIMA JUNIOR ${ }^{3}$, ANDRÉ LUIZ PEREIRA DA \\ SILVA $^{4}$, GLEDSON LUIZ SALGADO DE CASTRO ${ }^{2}$, RAFAELLE FAZZI GOMES ${ }^{3}$
}

\begin{abstract}
Considering the lack of technical information on the water depth and nitrogen fertilization via fertigation in protected cultivation for bell pepper production in northern Brazil, this paper aimed to study the soil water tensions under different nitrogen doses for the cultivation of bell pepper in protected environment. The experiment was conducted in a greenhouse at the Igarapé-Açu School Farm of the Federal Rural University of the Amazon, at $1.0 \times 0.50 \mathrm{~m}$ spacing, using the experimental design of randomized blocks in a $5 \times 4$ factorial scheme, with three replicates. The treatments consisted of five soil water tensions $(15,25,35,45$ and $65 \mathrm{kPa})$ and four nitrogen doses $\left(0,135,265\right.$ and $\left.395 \mathrm{~kg} \mathrm{ha}^{-1}\right)$. There was interaction between soil water tension and nitrogen doses only for nitrogen use efficiency, and the best value was obtained with the combination between soil water tension of $15 \mathrm{kPa}$ and nitrogen dose of $135 \mathrm{~kg} \mathrm{ha}^{-1}$. Total number of fruits, fruit length and fruit diameter showed significant differences only as a function of soil water tensions. Production per plant, total yield and water use efficiency were statistically significant for soil water tensions and nitrogen doses. Therefore, for the conditions in which this study was carried out, it is recommended to apply a soil water tension of $15 \mathrm{kPa}$ and nitrogen dose of $265 \mathrm{~kg} \mathrm{ha}^{-1}$ for bell pepper cultivation in protected environment.
\end{abstract}

Keywords: Protected cultivation. Drip irrigation. Tensiometry.

\section{PRODUÇÃO DE PIMENTÃo FERTIRRIGADO SOB DIFERENTES TENSÕES DE ÁGUA NO SOLO E ADUBAÇÃO NITROGENADA}

RESUMO - Tendo em vista a carência de informações técnicas sobre a lâmina de água e adubação com nitrogênio via fertirrigação em cultivo protegido para produção de pimentão na região norte do Brasil. Este trabalho foi realizado objetivando-se estudar tensões de água no solo sob diferentes doses de nitrogênio, para o cultivo de pimentão em cultivo protegido. O experimento executado em casa de vegetação na Fazenda Escola de Igarapé Açu da Universidade Federal Rural da Amazônia, no espaçamento 1,0 x 0,50 m, em delineamento de blocos casualizados, esquema fatorial $5 \times 4$, com três repetições. Os tratamentos foram constituídos por cinco tensões de água no solo $(15,25,35,45$ e $65 \mathrm{kPa})$ e quatro doses de nitrogênio $\left(0,135,265\right.$ e $\left.395 \mathrm{~kg} \mathrm{ha}^{-1}\right)$. Houve interação entre os fatores tensão de água no solo e doses de nitrogênio apenas para eficiência no uso de nitrogênio, obtendo melhor índice na combinação $15 \mathrm{kPa}$ de água no solo e $135 \mathrm{~kg} \mathrm{ha}^{-1}$ de nitrogênio. Número total de frutos, comprimento e diâmetro de frutos tiveram diferença significativa apenas para as tensões de água no solo. Produção por planta, produtividade total, eficiência no uso da água foram estatisticamente significativas para as tensões de água no solo e doses de nitrogênio. Logo, recomenda-se a tensão de $15 \mathrm{kPa}$ de água no solo e dose de $265 \mathrm{~kg} \mathrm{ha}^{-1}$ de nitrogênio, para o cultivo de pimentão em ambiente protegido.

Palavras-chave: Cultivo protegido. Irrigação por gotejamento. Tensiometria.

\footnotetext{
*Corresponding author

${ }^{1}$ Received for publication in $02 / 22 / 2019$; accepted in $11 / 28 / 2019$.

Paper extracted from the dissertation mastter's of the first author.

${ }^{2}$ Universidade Federal Rural da Amazônia, Belém, PA, Brazil; aguiar.helane@gmail.com - ORCID: 0000-0002-4818-3569, gledsoncastro87@gmail.com - ORCID: 0000-0002-3126-6720.

${ }^{3}$ Universidade Federal Rural da Amazônia, Capanema, PA, Brazil; joaquimjunioralves13@gmail.com - ORCID: 0000-0001-9003-7998, rafaelle.fazzi.gomes@gmail.com - ORCID: 0000-0001-8242-8104.

${ }^{4}$ Vegetables Production Department, Universidade Estadual Paulista Júlio de Mesquita Filho, Jaboticabal, SP, Brazil; andreengagronomo@gmail.com - ORCID: 0000-0002-4793-4690.
} 


\section{INTRODUCTION}

Bell pepper (Capsicum annuum var. annuum) is one of the most cultivated and consumed Solanaceae species in Brazil (LORENZONI et al., 2015), putting the country among the largest producers in the world (OLIVEIRA et al., 2015), which makes this vegetable highly economically important in the national market.

The average production of bell pepper in Brazil is $22 \mathrm{t} \mathrm{ha}^{-1}$, occupying an area of $15,000 \mathrm{ha}$, with production of 334,615 tons (ROCHA, 2017). The main producing states are Minas Gerais, São Paulo, Ceará, Rio de Janeiro, Espírito Santo and Pernambuco (87\% of the total) (HF BRASIL/ CEPEA, 2017).

According to the latest survey of the Brazilian Institute of Geography and Statistics - IBGE (BRASIL, 2006), the northern region has the lowest agricultural production of bell pepper, 2,034 tons. Possibly this production must have increased, because the Amazonas state has been leveraging its production in protected cultivation using fertigation (MAROUELLI; SILVA, 2014).

In the state of Pará, the northeast region is in a prominent position in the production of vegetables. However, the production of non-traditional vegetables, such as bell pepper, is still incipient due to the lack of technical and economic information about the crop in the state. This ultimately forces the import of this food, which increases its commercial value in the state.

Although there is positive growth in production systems, limiting costs without affecting yield (ROCHA, 2017), the main obstacles to a more significant increase of this production are the adequate managements of water and nutrients (OLIVEIRA et al., 2015).

In order to obtain greater control over these obstacles in bell pepper cultivation in a protected environment, producers have adopted fertigation, which according to Marouelli and Silva (2014) is defined as the process of applying fertilizers simultaneously with irrigation water, supplying the amounts of nutrients required by the crop at the adequate time.

The most adequate irrigation management for excellent fertigation is tensiometry (CARVALHO et al., 2013), which measures the "force" with which water is retained by the soil, which affects the absorption of water by plants, being used to indicate the appropriate time to perform irrigations (MAROUELLI, 2008).

Research indicates variations in water demand in the cultivation of bell pepper, as it is sensitive to extreme variations in soil water. According to Marouelli and Silva (2012), the crop has water need between 450 and $650 \mathrm{~mm}$, possibly reaching 1,250 mm (DOORENBOS; KASSAM, 1994), as this demand varies according to climatic conditions, cycle duration, and the adopted cultivation and irrigation systems (MAROUELLI; SILVA, 2014).

Associated with the water management required for bell pepper crop, the need for nutrients has received a lot of attention (ALBUQUERQUE et al., 2012), especially nitrogen, as it is absorbed in varied amounts throughout the cultivation cycle and directly influences plant growth (ARAGÃO et al., 2012).

This nutrient is one of the main macronutrients required by bell pepper, influencing its production and inducing rapid development of this crop. In excess, it causes flower abortion and delayed maturity, while making the crop more susceptible to diseases (LORENZONI et al., 2015).

Therefore, this work was conducted to study soil water tensions under different nitrogen doses for the cultivation of bell pepper in protected environment.

\section{MATERIAL AND METHODS}

The study was carried out in a protected environment, covered by 150 -micron-thick plastic film and 50\% shade net, located at the Igarapé-Açu School Farm of the Federal Rural University of the Amazon (FEIGA/UFRA), at the geographical coordinates $1^{\circ} 07^{\prime} 48.47^{\prime}, \mathrm{S}$ and $47^{\circ} 36^{\prime} 45.31^{\prime \prime} \mathrm{W}$, in the municipality of Igarapé-Açu, northeastern Pará, Brazil.

The experimental design was in randomized blocks in a $5 \times 4$ factorial scheme, with three replicates. The treatments consisted of five soil water tensions $(15,25,35,45$ and $65 \mathrm{kPa})$, as an indication of the moment to irrigate - critical tension, and four nitrogen doses $\left(0 ; 135,265\right.$ and $\left.395 \mathrm{~kg} \mathrm{ha}^{-1}\right)$ based on the nutrient absorption curve for fertigated bell pepper (RINCÓN et al., 1995), corresponding to 0 , 45,90 and $135 \%$ of the nitrogen dose recommended by these authors.

The hybrid used was DAHRA RX and the seedlings were prepared on polyethylene trays, filled with organic compost. At 30 days after sowing (DAS), with average height of $15 \mathrm{~cm}$, the seedlings were transplanted. They were irrigated for 30 days, before the differentiation of treatments, for better establishment, thus totaling a depth of $199.08 \mathrm{~mm}$ $\left(6.64 \mathrm{~mm} \mathrm{day}^{-1}\right)$. Following these 30 days after transplantation (DAT), the treatments began to be differentiated.

Soil tillage was carried out 30 days before transplantation through the application of limestone in the $0-20 \mathrm{~cm}$ layer, incorporated with a hoe, using the base saturation method according to the soil 
analysis (Table 1) to correct soil acidity and elevate base saturation (V) to $80 \%$, with a 30 -period of reaction. One week before transplanting the seedlings, basal fertilization was performed with Topmix $^{\mathrm{Tm}}(08.40 .08+\mathrm{S}+$ micronutrient $-\mathrm{Zn}, \mathrm{B}, \mathrm{Cu}$ and $\mathrm{Mn}), 50 \mathrm{~g} \mathrm{~m}^{-2}$, in all plots.

Table 1. Chemical analysis of the soil.

\begin{tabular}{|c|c|c|c|c|c|c|c|c|c|c|c|c|c|}
\hline \multirow{3}{*}{ Depth } & \multicolumn{13}{|c|}{ Chemical analysis } \\
\hline & \multicolumn{4}{|c|}{ Macronutrients } & \multicolumn{4}{|c|}{ Micronutrients } & \multicolumn{2}{|c|}{ Acidity } & \multicolumn{3}{|c|}{ Others } \\
\hline & $\mathrm{K}$ & $\mathrm{P}$ & $\mathrm{Ca}$ & $\mathrm{Mg}$ & $\mathrm{Cu}$ & $\mathrm{Fe}$ & $\mathrm{Mn}$ & $\mathrm{Zn}$ & $\overline{\mathrm{pH}}$ & $\overline{\mathrm{H}+\mathrm{Al}}$ & $\mathrm{V}$ & CEC & $\mathrm{OM}$ \\
\hline $\mathrm{cm}$ & $\begin{array}{l}\mathrm{mg} \\
\mathrm{dm}^{-3}\end{array}$ & & $\mathrm{c} \mathrm{dm}$ & & ---- & $--m g d n$ & -- & & $\mathrm{H}_{2} \mathrm{O}$ & $\begin{array}{l}\text { cmolc } \\
\mathrm{dm}^{-3}\end{array}$ & $\%$ & $\begin{array}{l}\text { cmolc } \\
\mathrm{dm}^{-3}\end{array}$ & $\begin{array}{l}\mathrm{g} \\
\mathrm{kg}^{-1}\end{array}$ \\
\hline $0-20$ & 74 & 26 & 1.6 & 0.8 & 0.95 & 493.64 & 6.65 & 2.31 & 4.7 & 3.63 & 42.13 & 6.27 & 11.37 \\
\hline
\end{tabular}

Source: Soil Analysis Laboratory of Embrapa Eastern Amazon.

The localized irrigation system adopted was a drip system, with average flow rate of $2.32 \mathrm{~L} \mathrm{~h}^{-1}$ per dripper, and emitters spaced by $15 \mathrm{~cm}$. Irrigation was performed using drip hoses with nominal diameter of $16 \mathrm{~mm}$, at operating pressure of $7.5 \mathrm{~m}$.w.c. measured by a manometer at the end of the hose. The drip hoses were positioned within the plot and each hose supplied one row of plants (3.5 drippers/plant). The irrigation system comprised a 3,000-L water tank, a 1.5-hp electric pump (flow rate of $10 \mathrm{~m}^{3} / \mathrm{h}$ ), actuated by the controller, and a disc filter.

After the irrigation system was installed, a hydraulic evaluation was performed to determine its performance, using the Distribution Uniformity Coefficient (DUC). Uniformity analysis was conducted in 30 plots, by placing $180-\mathrm{mL}$ collectors under four emitters, collecting water for a period of 1 min, in two replicates. After obtaining the means of the collected water depths, DUC was calculated and the system was classified as excellent (96\%) according to the classification of Mantovani (2001).

To determine the critical tension, a set of two puncture tensiometers was installed at $20 \mathrm{~cm}$ depth, indicating the moment of irrigation, and one at $30 \mathrm{~cm}$ depth to check if water loss was occurring. The tensiometers were positioned along the crop row, $15 \mathrm{~cm}$ away from the drippers. Tensiometer readings were taken once a day, at the same time, using a digital puncture tensimeter.

Irrigation management was based on the soil water characteristic curve obtained in the profile from 0 to $30 \mathrm{~cm}$, fitted according to the model proposed by Van Genuchten (1980) (Figure 1). The irrigations were performed when the average reading of the tensiometers reached the critical tension, always seeking to bring the soil to field capacity, which corresponded to the tension of $10 \mathrm{kPa}$ $\left(0.339 \mathrm{~cm}^{3} \mathrm{~cm}^{-3}\right)$.

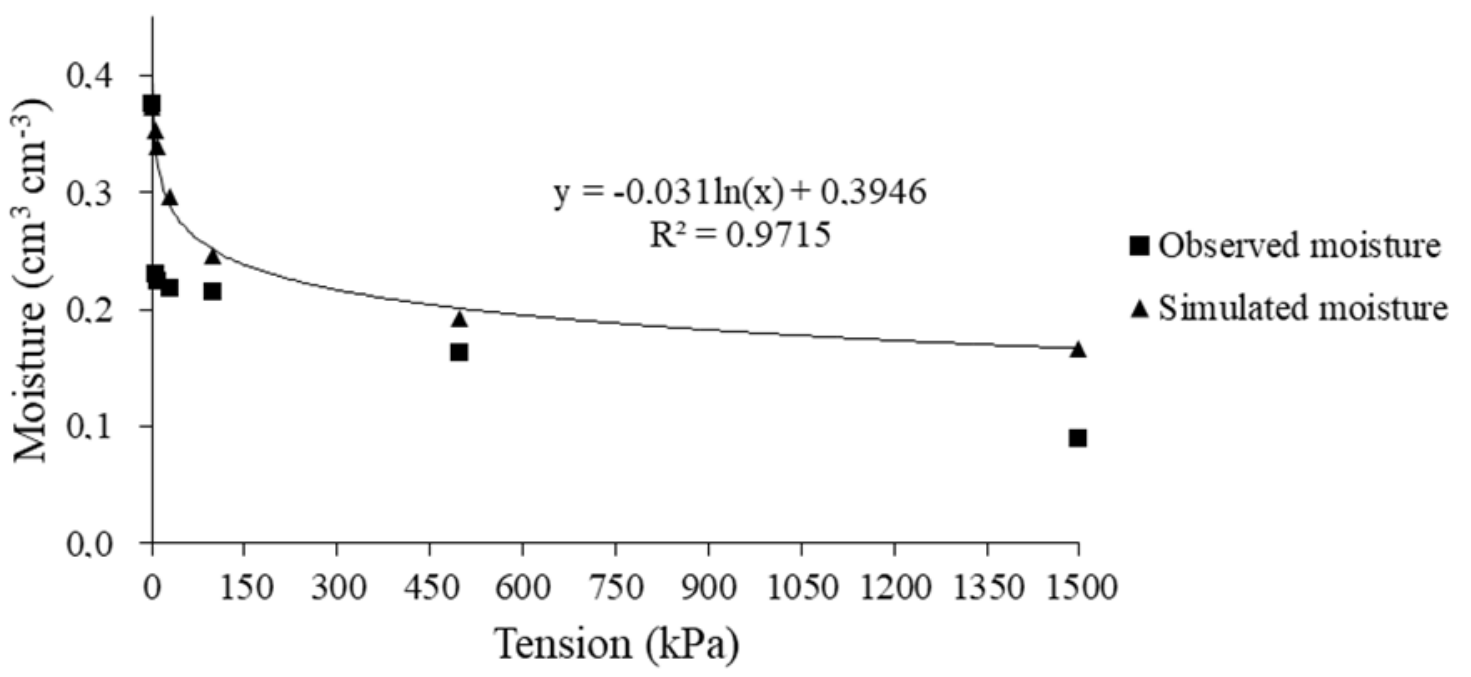

Figure 1. Soil water retention curve.

The water depths applied in the differentiation of treatments and the operating time of the irrigation system were calculated according to Cabello (1996), considering the effective depth of the root system, equal to $20 \mathrm{~cm}$, because approximately $80 \%$ of the roots of the crop are concentrated at this depth (MAROUELLI, 2008).

The fertilizers were injected using the injecting pump system, in which the fertilizer solution contained in the open reservoir was introduced in the irrigation system, with pressure $10 \%$ higher than that at the discharge pipe, at constant concentration, by the 1-hp electric pump $\left(9.8 \mathrm{~m}^{3} / \mathrm{h}\right)$, actuated by the controller. A manometer was installed after the disc filter to better control the operating pressure of the system. 
The fertilizers were applied in the form of mixture. The solutions were prepared separately and mixed, in the desired proportion, according to the treatments, always paying attention to the solubility and compatibility of the sources used. Also, before injection, the electrical conductivity of the concentrated nutrient solution $\left(\mathrm{dS} \mathrm{m}^{-1}\right)$ was checked.
Therefore, the amount corresponding to the demand for each treatment was weighed, identified and diluted in water (paying attention to solubility and compatibility), based on the absorption curve of fertigated bell pepper (RINCÓN et al., 1995) (Table 2).

Table 2. Nutrient absorption curve used as reference

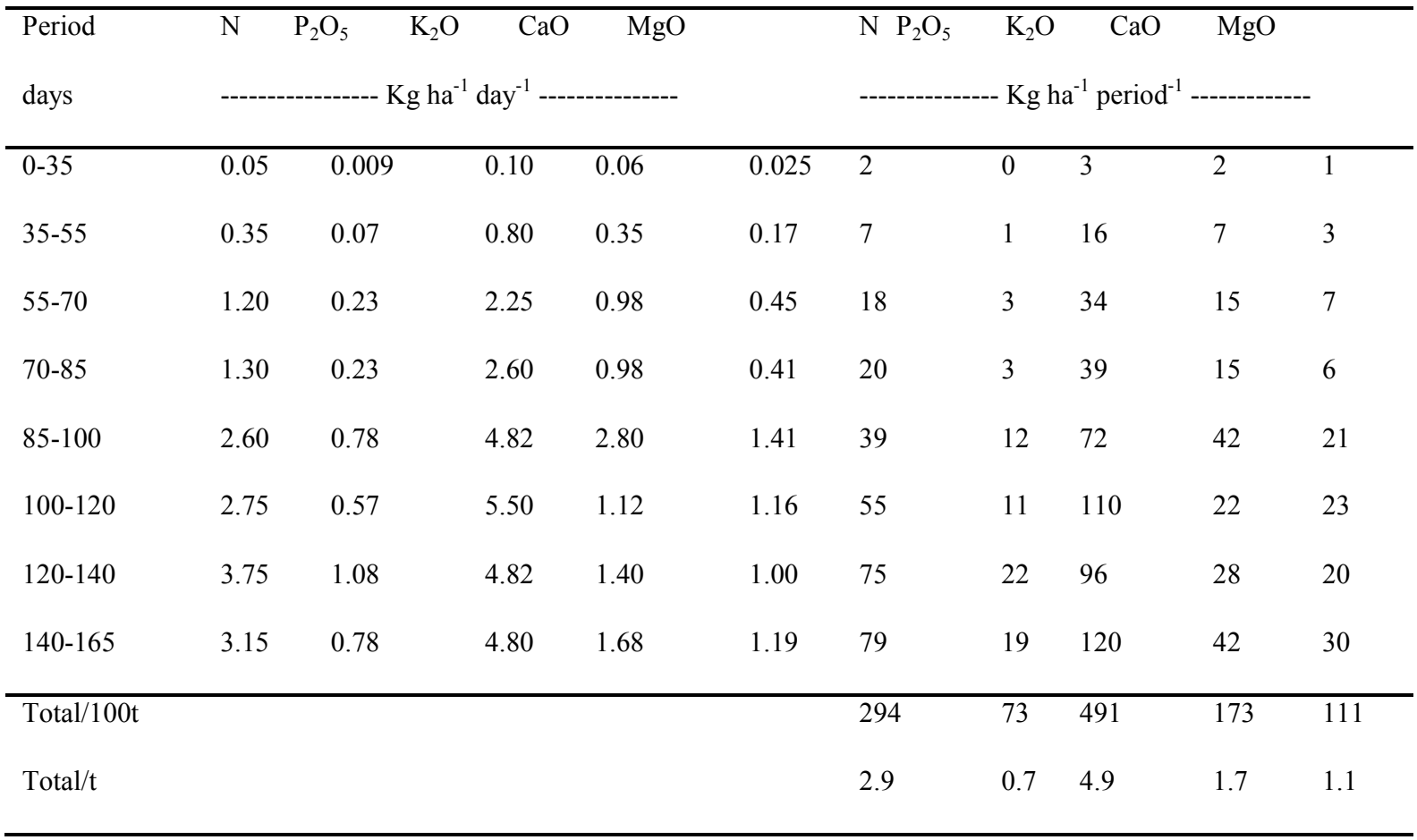

Source: Rincón et al. (1995)

The fertilizers used in the nutrient solution of fertigation were: calcium nitrate, potassium nitrate, magnesium nitrate, urea, calcium chloride, potassium chloride (white powder), purified MAP, monopotassium phosphate and magnesium sulfate. The fertilizers were applied according to the replacement of the irrigation depths for the tension corresponding to each treatment.

Soil solution monitoring was carried out using extractors, which were installed at $20 \mathrm{~cm}$ depth, following the same methodology adopted for tensiometer installation. To extract the solution from the soil, vacuum was applied to all extractors after fertigation. After 24 hours from this application, the solution was extracted with a $60-\mathrm{mL}$ plastic syringe and analyzed with a portable multiparameter meter $\left(\mathrm{AKSO}^{\circledR}\right.$ Combo5) for hydrogen potential $(\mathrm{pH})$, electrical conductivity (EC), salinity (Sal) and total dissolved solids (TDS).

The variables evaluated were: total number of fruits per plant (TNF), fruit length (FL), fruit diameter (FD), average production per plant (APP), total yield (YIELD total $_{\text {) }}$, water use efficiency (WUE) and nitrogen use efficiency (NUE).

Three harvests were performed throughout the experimental period, starting at 72 DAT, with 20-day intervals, and the harvesting point was indicated by the bright green color of the fruits, which were harvested from five usable plants in each plot. These fruits were then weighed to obtain the production per plant and total yield, the latter of which according to Equation 1.

$$
\text { YIELDtotal }=\frac{\text { total } \text { production }}{\text { area }} \quad(\text { Equation } 1)
$$

Where:

YIELD $_{\text {total }}=$ Total yield, $\mathrm{t} \mathrm{ha}^{-1}$

Total production $=$ Total fruit production, $\mathrm{t}$

Area $=$ Area, ha

Water use efficiency (WUE) was obtained as the ratio between total fruit production $(\mathrm{kg})$ and water consumption (mm) along the crop cycle (DOORENBOS; KASSAM, 1994), according to Equation 2:

$$
W U E=\frac{P R O D \text { total }}{w}
$$

(Equation 2) 
Where:

WUE $=$ water use efficiency, $\mathrm{kg} \mathrm{mm}^{-1}$

YIELD $_{\text {total }}=$ total yield, $\mathrm{kg} \mathrm{ha}^{-1}$

$\mathrm{w}=$ water volume applied, $\mathrm{mm} \mathrm{ha}^{-1}$

Nitrogen use efficiency (NUE) was obtained as the ratio between total yield and nitrogen dose applied, according to Equation 3:

$$
N U E=\frac{P R O D \text { total }}{N \text { dose }} \quad(\text { Equation } 3)
$$

Where:

$\mathrm{NUE}=$ nitrogen use efficiency, $\mathrm{kg}$ of fruits $/ \mathrm{kg}$ of nitrogen

YIELD $_{\text {total }}=$ total yield, $\mathrm{kg} \mathrm{ha}^{-1}$

$\mathrm{N}$ dose $=\mathrm{kg} \mathrm{ha}^{-1}$
Effects of soil water tension and nitrogen fertilization via fertigation on the evaluated variables were evaluated by $\mathrm{F}$ test and, when significant, regression analyses were applied at 5\% significance level using the program R 3.5.0.

\section{RESULTS AND DISCUSSION}

Data of the Davis Vantage Pro 2 station, installed within the protected environment, were used to monitor the agrometeorological variables and understand the behavior of plants. Variations in air temperature and relative humidity observed within the protected environment along the experiment are presented in Figure 2.

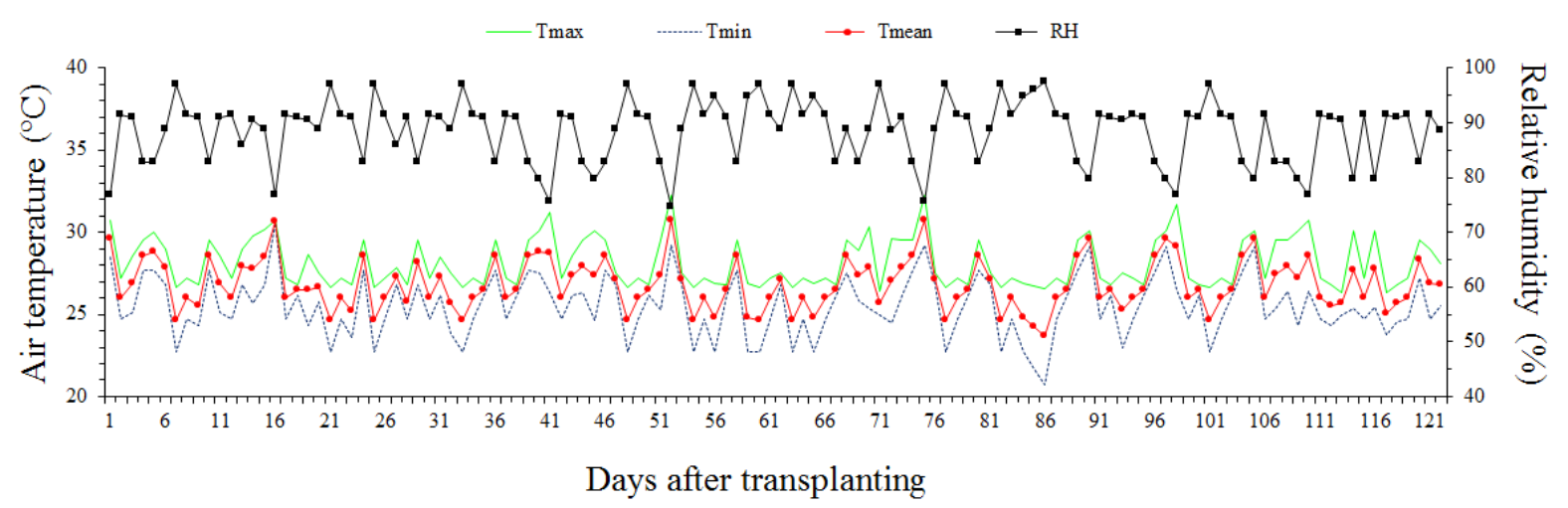

Figure 2. Means of air temperature and relative humidity obtained along the experiment.

In the experimental period, the average maximum and minimum temperatures observed were 30.7 and $24.2{ }^{\circ} \mathrm{C}$, respectively, being consistent with the values found by Oliveira et al. (2015). These values are close to those considered ideal for bell pepper development and production, and according to Pinto et al. (2007) the mean temperature must be between 26 and $30{ }^{\circ} \mathrm{C}$ and the minimum temperature around $17^{\circ} \mathrm{C}$.

The average values of maximum and minimum relative humidity were 97.3 and $74.6 \%$, respectively, Figure 2. There was an increase in relative humidity inside the greenhouse whenever the temperature decreased. The mean values of relative humidity analyzed inside the greenhouse were above the range considered ideal for the crop, which is from 50 to $70 \%$ according to Goto and Tivelli (1998).

With temperature peaks above $30^{\circ} \mathrm{C}$, calcium (Ca) deficiency was observed in all treatments, especially those with higher tensions, because low soil moisture, higher leaf transpiration intensity and nutritional imbalance influence the absorption, translocation and accumulation of $\mathrm{Ca}$ in plants, causing apical rot in fruits (CANTUÁRIO et al., 2014). This fact may have contributed to significant losses of yield in the treatments analyzed in this study.

Table 3 presents the water depths applied before (Init) and after (Irrig) the differentiation of treatments along the experiment, total water volume supplied to the crop until the harvests (Total), number of irrigations (NI), average irrigation interval (Int) and daily water demand (WD) during the differentiation of treatments. The treatments were differentiated only at 30 DAT.

It was observed that the total water depth applied was decreasing, so that the $15 \mathrm{kPa}$ tension was associated with higher water consumption, due to the greater number of irrigations, since this tension is close to the field capacity adopted in the experiment, Table 3.

According to the data obtained in this study, there was interaction between soil water tensions and nitrogen doses for nitrogen use efficiency, at 5\% significance level. Total number of fruits per plant, fruit length and fruit diameter showed significant differences only for soil water tensions. Average production per plant, total yield, water use efficiency showed significant differences for soil water tensions and nitrogen doses, which caused significant effects at $5 \%$ probability level (Table 4 ). 
H. C. A. SANTOS et al.

Table 3. Soil water tensions at $0.20 \mathrm{~m}$ depth, water depths applied before differentiation of treatments (Init), water depths applied after differentiation of treatments (Irrig), total water depth (Total), number of irrigations (NI), mean irrigation interval (Int) and daily water demand (WD) in bell pepper cultivation as a function of soil water tensions and nitrogen doses via fertigation, Igarapé-Açu - PA, Brazil.

\begin{tabular}{lccccccc}
\hline \multicolumn{2}{l}{ Water depths $(\mathrm{mm})$} & \multicolumn{7}{l}{} \\
\hline Treatments & Tension & Init & Irrig & Total & NI (un) & Int & WD (mm/day) \\
\hline T15 & $15 \mathrm{kPa}$ & 199.08 & 320.80 & 519.88 & 48 & 2.31 & 4.68 \\
T25 & $25 \mathrm{kPa}$ & 199.08 & 314.34 & 513.42 & 32 & 3.47 & 4.63 \\
T35 & $35 \mathrm{kPa}$ & 199.08 & 305.53 & 504.61 & 25 & 4.44 & 4.55 \\
T45 & $45 \mathrm{kPa}$ & 199.08 & 271.80 & 470.88 & 17 & 6.53 & 4.24 \\
T65 & $65 \mathrm{kPa}$ & 199.08 & 209.23 & 408.31 & 11 & 10.09 & 3.68 \\
\hline
\end{tabular}

Table 4. Summary of analysis of variance for total number of fruits per plant (TNF), fruit length (FL), fruit diameter (FD), average production per plant (APP), total yield $\left(\mathrm{YIELD}_{\text {total }}\right)$, water use efficiency (WUE) and nitrogen use efficiency (NUE) as a function of soil water tensions and nitrogen doses via fertigation in bell pepper, Igarapé Açu - PA, Brazil.

\begin{tabular}{|c|c|c|c|c|c|c|c|}
\hline \multirow{3}{*}{ Source of Variation } & \multicolumn{7}{|c|}{ F values } \\
\hline & TNF & FL & FD & APP & YIELD $_{\text {total }}$ & WUE & NUE \\
\hline & $\begin{array}{l}----- \\
-\end{array}$ & \multicolumn{2}{|c|}{------- mm ------ } & $\mathrm{kg} \mathrm{plant}^{-1}$ & $\mathrm{~kg} \mathrm{ha}^{-1}$ & $\mathrm{~kg} \mathrm{~mm}^{-1}$ & $\mathrm{~kg} \mathrm{~kg}^{-1}$ \\
\hline Block & $6.01 *$ & $2.77^{\mathrm{ns}}$ & $5.43^{*}$ & $4.86^{*}$ & $4.86^{*}$ & $4.71 *$ & $0.34^{\mathrm{ns}}$ \\
\hline Tension $(\mathrm{T})$ & $24.02 *$ & $20.84 *$ & $7.60 *$ & $47.96^{*}$ & $47.96^{*}$ & $25.80 *$ & $41.26^{*}$ \\
\hline Nitrogen $(\mathrm{N})$ & $2.89^{\mathrm{ns}}$ & $2.52^{\mathrm{ns}}$ & $0.38^{\mathrm{ns}}$ & $13.15^{*}$ & $13.16^{*}$ & $12.53 *$ & $67.88^{*}$ \\
\hline Interaction $\mathrm{T} \times \mathrm{N}$ & $0.12^{\mathrm{ns}}$ & $0.57^{\mathrm{ns}}$ & $0.61^{\mathrm{ns}}$ & $2.19^{\mathrm{ns}}$ & $2.18^{\mathrm{ns}}$ & $1.60^{\mathrm{ns}}$ & $7.71 *$ \\
\hline $\mathrm{CV}(\%)$ & 24.08 & 6.71 & 5.95 & 26.56 & 28.57 & 28.83 & 30.92 \\
\hline
\end{tabular}

The total number of fruits per plant, as a function of the increase in soil water tensions, followed a decreasing linear regression $(P<0.05)$.
The mean values decreased as the tensions increased until reaching the lowest point at the tension of 65 $\mathrm{kPa}$ (Figure 3).

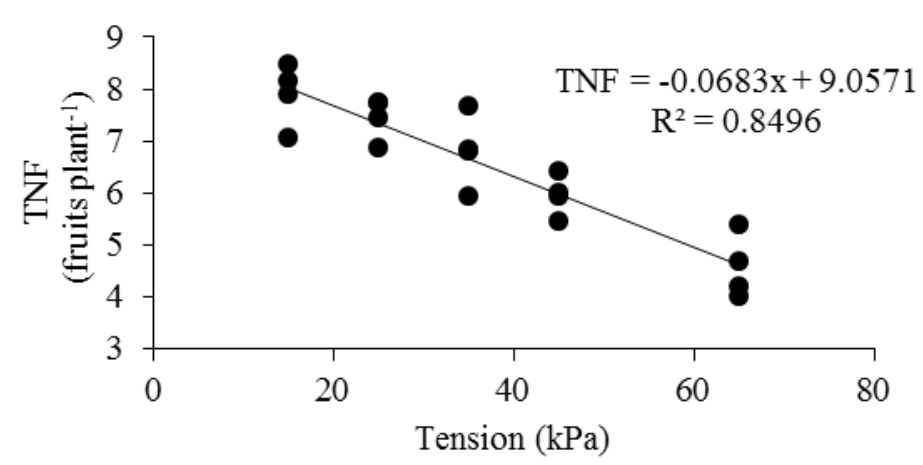

Figure 3. Effects of soil water tensions on the total number of fruits per plant (TNF) in bell pepper.

It was confirmed that the $15 \mathrm{kPa}$ tension led to the highest total number of fruits per plant, an average of 8 fruits plant ${ }^{-1}$, Figure 3 . In the results obtained by Carvalho et al. (2016), the average number of fruits per plant was 5.1, when the soil water tension reached $15 \mathrm{kPa}$. This leads to the inference that the variation in the average number of bell pepper fruits is influenced by the cultivation technique used and planting period.

The total number of fruits per plant decreased by $42.25 \%$ between the tensions of $15 \mathrm{kPa}$ and 65 $\mathrm{kPa}$, Figure 3. Such reduction in the number of fruits was caused by increased soil water tension, which led to low water availability, causing water stress in the crop and directly influencing its fruit production.
Water deficit is one of the main causes of stress on crops, especially on horticultural crops, as it causes disorders in plant development with reduction in leaf area, consequently reducing the photosynthetic rate (LOSS, 2017). Therefore, in this study the lower production and shorter length and diameter of fruits under the higher tensions may be related to the reduction in the photosynthetic process, because under low water availability, stomata close as a defense mechanism, in order to reduce water loss by transpiration because, for Sezen et al. (2011), the occurrence of water deficit before and during the initial flowering phase reduces the number of fruits due to flower abortion. 
Fruit length and diameter, as a function of the increase in soil water tensions, followed a decreasing linear regression $(P<0.05)$. The mean values decreased as the increasing tensions increased until reaching the lowest value at $65 \mathrm{kPa}$ (Figure $4 \mathrm{~A}$ and $\mathrm{B}$ ).

(A)
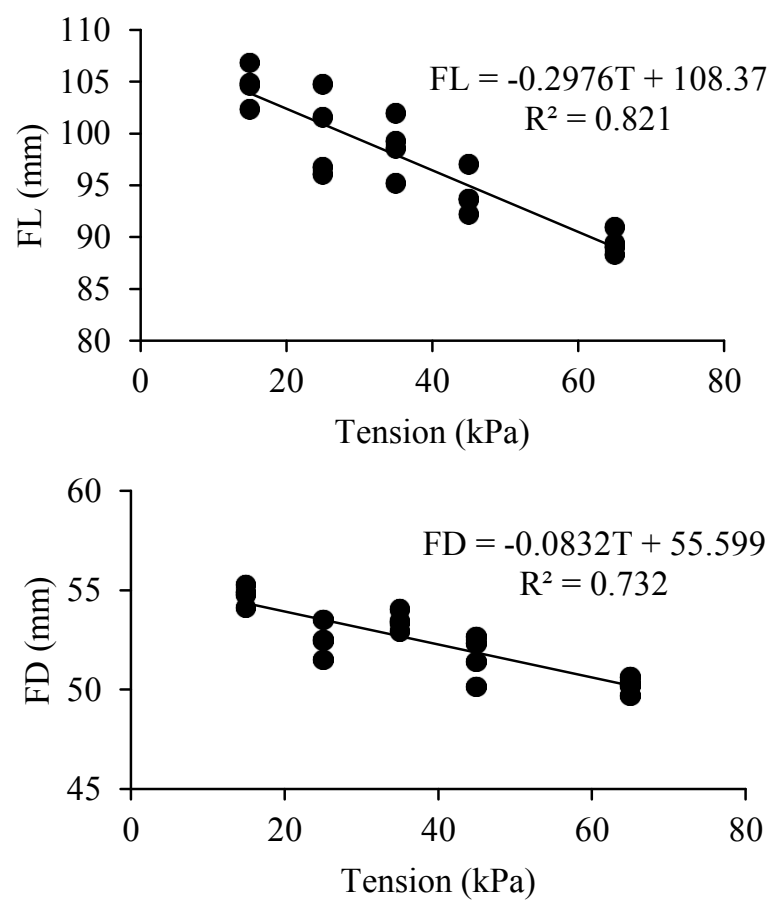

(B)

Figure 4. Effects of soil water tensions on fruit length (FL) (A) and fruit diameter (FD) (B) in bell pepper.

The highest value of fruit length $(103.91 \mathrm{~mm})$ was observed at soil water tension of $15 \mathrm{kPa}$, showing a $14.33 \%$ reduction compared to the tension of $65 \mathrm{kPa}$. Fruit diameter showed a similar behavior to that of fruit length, as the largest diameter (54.35 $\mathrm{mm}$ ) was obtained under soil water tension of 15 $\mathrm{kPa}$, with a $7.69 \%$ reduction compared to the tension of $65 \mathrm{kPa}$, Figure 4.

Carvalho et al. (2013), working with soil water tensions in bell pepper cultivation, found that the $15 \mathrm{kPa}$ tension led to the highest mean values of fruit length and diameter, around 52 and $49.5 \mathrm{~mm}$, respectively, which are lower than those found in the present study. On the other hand, Carvalho et al. (2011) applied a water depth of $748 \mathrm{~mm}$ and observed higher mean values of fruit length and diameter compared to those found in the present study, around 125 and $75 \mathrm{~mm}$, respectively.

The average production per plant as a function of soil water tensions and increasing nitrogen doses followed a linear trend and a quadratic curve, respectively $(P<0.05)$. The average production per plant decreased progressively as a function of the increase in soil water tensions, with lowest mean value at $65 \mathrm{kPa}$. For the nitrogen doses factor, the average production per plant increased as the nitrogen doses increased until reaching the highest mean value at the dose of $265 \mathrm{~kg} \mathrm{ha}^{-1}$ and then progressively decreased (Figure $5 \mathrm{~A}$ and $\mathrm{B}$ ).

In regard to the average production per plant, the highest bell pepper production (678.98 $\mathrm{g}$ plant $^{-1}$ ) was found under soil water tension of $15 \mathrm{kPa}$, showing a $61.59 \%$ reduction when compared to the tension of $65 \mathrm{kPa}$, Figure 5. Carvalho et al. (2013), working with bell pepper in protected cultivation, also found that the tension of $15 \mathrm{kPa}$ promotes better production performance.

Nitrogen doses led to a quadratic trend curve, and the optimal nitrogen dose estimated by the fitting equation $\left(\mathrm{R}^{2}>0.7\right)$ was $240.21 \mathrm{~kg} \mathrm{ha}^{-1}$, which represented maximum average production per plant of $588.09 \mathrm{~g} \mathrm{plant}^{-1}$, Figure 5. Likewise, Lorenzoni et al. (2015) analyzed the effect of $\mathrm{N}$ levels on bell pepper production, in $\mathrm{g}$ plant $^{-1}$, and found similar results, fitted with a second-degree polynomial model, with a decrease of production from the nitrogen dose of $155.95 \mathrm{~kg} \mathrm{ha}^{-1}$; at this maximum point the production corresponded to 546.31 g plant $^{-1}$. 
(A)

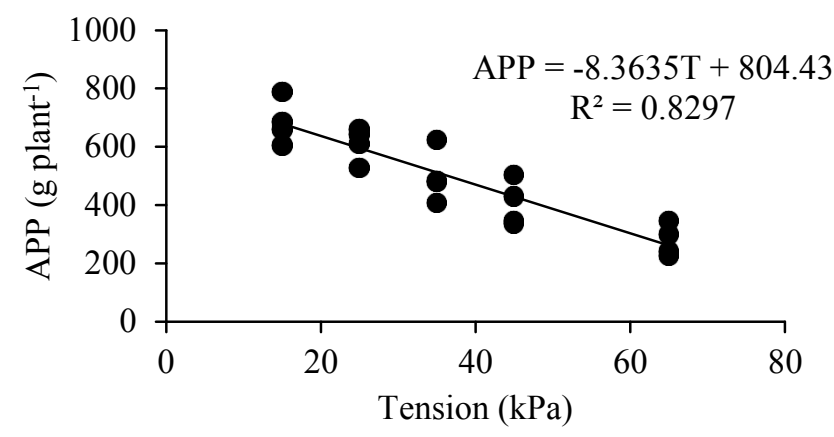

(B)

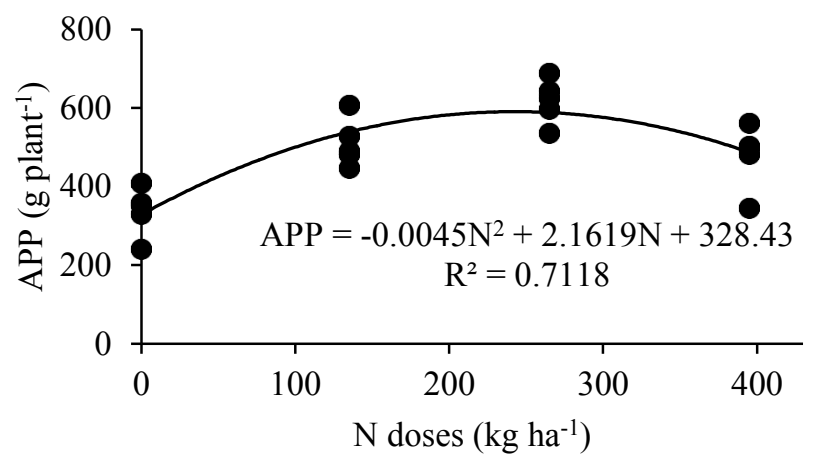

Figure 5. Effect of soil water tensions (A) and nitrogen doses (B) on the average production per plant (APP) in bell pepper.

Total yield $\left(\mathrm{t} \mathrm{ha}^{-1}\right)$, as a function of soil water tensions and increasing nitrogen doses, followed a linear trend and a quadratic curve, respectively $(P<$ $0.05)$. The mean values of total yield decreased progressively as a function of the increase in soil water tensions, with lowest average value at $65 \mathrm{kPa}$.
For the nitrogen doses factor, the total yield increased as a function of the increase in nitrogen doses until reaching the highest value at the dose of $265 \mathrm{~kg} \mathrm{ha}^{-1}$ and then progressively decreased (Figure $6 \mathrm{~A}$ and $\mathrm{B}$ ).

(A)

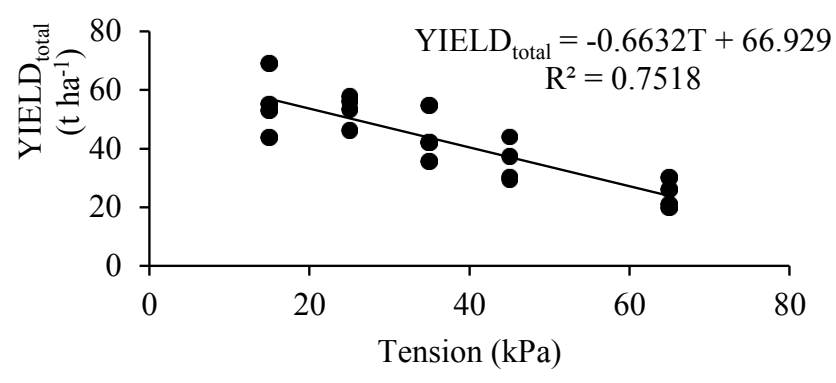

(B)

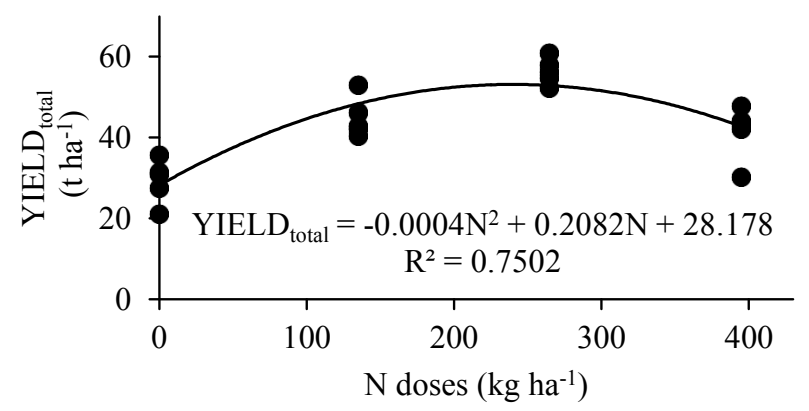

Figure 6. Effects of soil water tensions (A) and nitrogen doses (B) on the total yield (YIELD total $_{\text {) }}$ of bell pepper. 
It was observed that the total yield decreased by $58.20 \%$ between the tensions of $15 \mathrm{kPa}$ and 65 $\mathrm{kPa}$, with $75.18 \%$ of the variation in yield caused by the variation in soil water tensions, Figure 6 . Such reduction was influenced by the quantity and fresh mass of fruits, highly affected at the tension of 65 $\mathrm{kPa}$, because according to Marouelli and Silva (2014) the soil water content is one of the main factors affecting the yield of vegetables, since water is required as an integral part of the fruits, playing a major role in the transport of nutrients, among other vital functions for plant development.

The better performance of bell pepper with the application of $15 \mathrm{kPa}$ tension $(519.88 \mathrm{~mm})$ possibly enabled adequate water supply in soil and better availability of this resource and nutrients for the crop. Considering also that this treatment had higher number of irrigations (48 irrigations) compared to the others, it directly influenced the rate of nitrogen absorption by the crop, Figure 6 .

The optimal nitrogen dose for total yield per plant was estimated by the fitting equation $\left(\mathrm{R}^{2}>0.7\right)$ as $260.25 \mathrm{~kg} \mathrm{ha}^{-1}$, for a maximum total yield of 55.27 $\mathrm{t} \mathrm{ha}^{-1}$, Figure 6 . It is important to note that this yield was estimated only for three harvests conducted along the present study. However, it was probably affected by the occurrence of high temperatures during the flowering period, associated also with the values of relative humidity outside the limits tolerated by the crop and $\mathrm{Ca}$ deficiency.

The ideal nitrogen dose for the maximum yield found in the present study was $260.25 \mathrm{~kg} \mathrm{ha}^{-1}$. According to Filgueira (2008), it may be related to the efficiency of nitrogen in increasing bell pepper production, as well as the form of application through the fertigation system, in which nutrients are supplied at appropriate doses and time for each phase of the phenological stage of the crop. It can be noted that the increase in nitrogen fertilization from the dose that led to maximum yield causes its reduction, resulting in fertilizer waste and showing the importance of a correct fertilization for bell pepper yield.

Water use efficiency $\left(\mathrm{kg} \mathrm{mm}^{-1}\right)$, as a function of soil water tensions and increasing nitrogen doses, followed a linear trend and a quadratic curve, respectively $(P<0.05)$. The mean values water use efficiency decreased progressively as soil water tensions increased, with lowest value at $65 \mathrm{kPa}$. Conversely, for the nitrogen doses factor, water use efficiency increased as a function of the increment in nitrogen doses until reaching the highest mean value at the dose of $265 \mathrm{~kg} \mathrm{ha}^{-1}$ and then progressively decreased (Figure $7 \mathrm{~A}$ and $\mathrm{B}$ ).

(A)

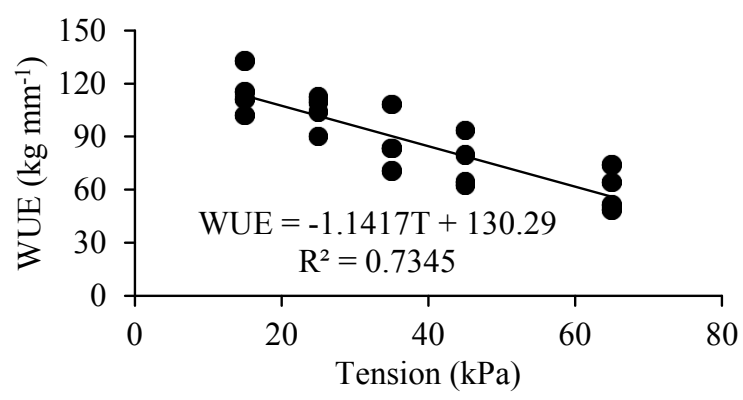

(B)

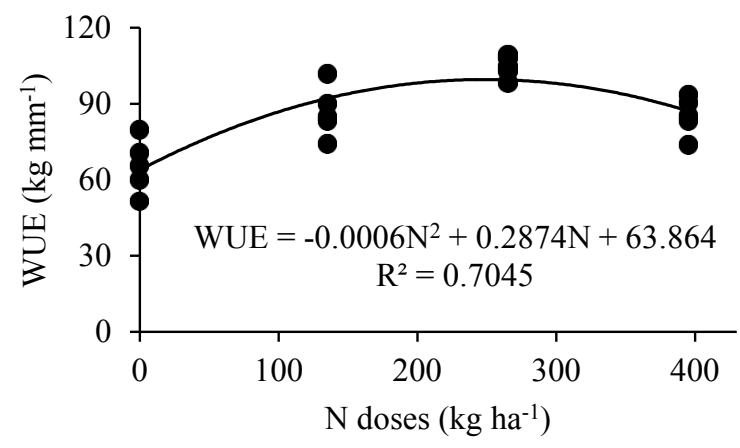

Figure 7. Effects of soil water tension (A) and nitrogen doses (B) on the water use efficiency (WUE) of bell pepper.

The highest value of water use efficiency $\left(113.16 \mathrm{~kg} \mathrm{~mm}^{-1}\right)$ was found at soil water tension of $15 \mathrm{kPa}$, showing a $50.44 \%$ reduction compared to the tension of $65 \mathrm{kPa}$. In relation to the nitrogen doses, the data followed a quadratic trend curve and the optimal nitrogen dose estimated by the fitting equation $\left(\mathrm{R}^{2}>0.7\right)$ was $239.5 \mathrm{~kg} \mathrm{ha}{ }^{-1}$, which represented maximum water use efficiency of 98.28 $\mathrm{kg} \mathrm{mm}^{-1}$, Figure 7. For Lima Junior et al. (2010), this parameter is essential for obtaining high levels of production, especially for vegetable crops that are extremely sensitive to variations in soil moisture. 
Carvalho et al. (2011), studying red bell peppers, found the highest estimated WUE of 74.76 $\mathrm{kg} \mathrm{mm}{ }^{-1}$ for a water depth of $334.1 \mathrm{~mm}$. The water depth found for the WUE was much lower than that observed in the present study, which can be explained by the microclimate formed inside the greenhouse, crop evapotranspiration, low soil moisture, fruit abortion, among other factors.
Nitrogen use efficiency was influenced by the interaction between soil water tensions and nitrogen doses, following a linear trend $(P<0.05)$. The highest mean value of NUE was obtained in the interaction between the tension of $15 \mathrm{kPa}$ and the nitrogen dose of $135 \mathrm{~kg} \mathrm{ha}^{-1}$, which led to $420.47 \mathrm{~kg}$ $\mathrm{kg}^{-1}$, showing a $63.03 \%$ reduction compared to the dose of $395 \mathrm{~kg} \mathrm{ha}^{-1}$, at which the NUE was equal to $155.45 \mathrm{~kg} \mathrm{~kg}^{-1}$, for the same tension (Figure 8).

\section{$\bullet 135 \mathrm{~N}(\mathrm{D} 1) \quad \boldsymbol{\square} 265 \mathrm{~N}(\mathrm{D} 2) \quad \boldsymbol{\Delta} 395 \mathrm{~N}(\mathrm{D} 3)$}

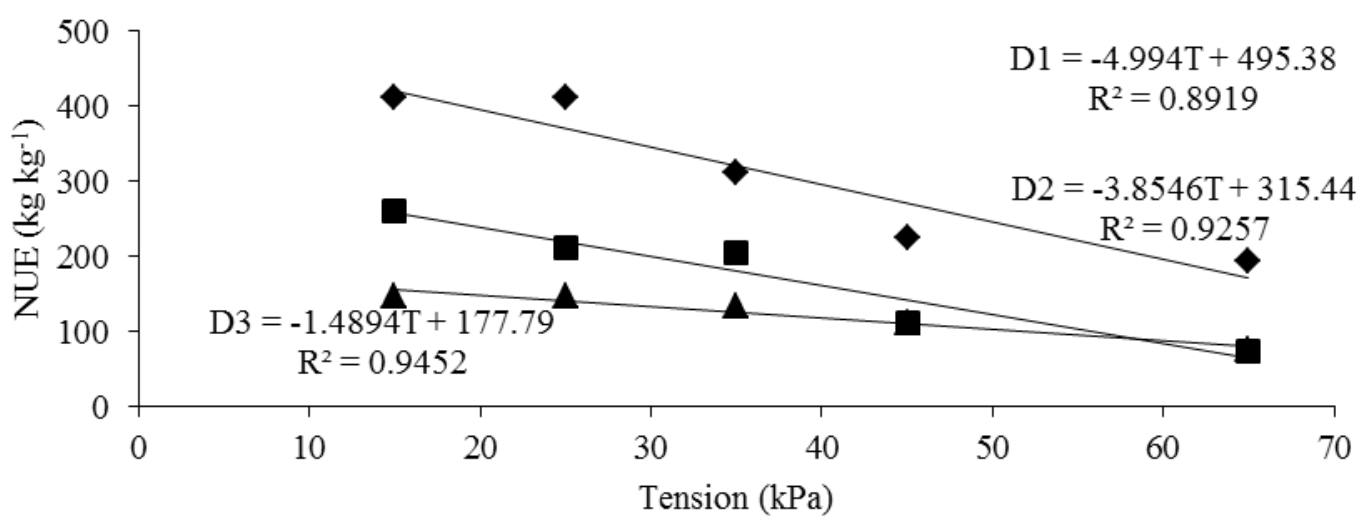

Figure 8. Effect of the interaction between soil water tensions and nitrogen doses via fertigation on the nitrogen use efficiency (NUE) of bell pepper.

For Monteiro et al. (2008), the use of this indicator of efficiency in the response of crops is a valuable source of information to be used in decision -making models, enabling the optimization of the use of the factors involved in production, especially when accompanied by the evaluation of water use efficiency.

It is possible to note that nitrogen use efficiency was not calculated for treatments without $\mathrm{N}$ application, since the efficiency considers the $\mathrm{N}$ applied to the soil and, in this case, it did not occur. As the $\mathrm{N}$ dose applied increased, the nitrogen use efficiency of all treatments decreased, agreeing with data reported by Todeschini et al. (2016), who observed that corn and wheat hybrids, respectively, were less efficient in $\mathrm{N}$ use under high levels of nitrogen supplement.

The highest value of NUE was $420.47 \mathrm{~kg}$ of bell pepper $\mathrm{kg}^{-1}$ of $\mathrm{N}$ applied, observed at the nitrogen dose of $135 \mathrm{~kg} \mathrm{ha}^{-1}$, which is $10 \%$ lower than the dose recommended for the crop by the fertilization bulletin of the Pará state.

\section{CONCLUSIONS}

For the conditions under which this study was conducted and from the results obtained for bell pepper cultivation in a greenhouse, it is possible to conclude that:

The variables number of fruits, fruit length and fruit diameter obtained better results under soil water tension of $15 \mathrm{kPa}$, with 8 fruits plant ${ }^{-1}, 103.91 \mathrm{~mm}$ and $54.35 \mathrm{~mm}$, respectively.

Maximum fruit production per plant was estimated under soil water tension of $15 \mathrm{kPa}$ and nitrogen dose of $240.21 \mathrm{~kg} \mathrm{ha}^{-1}$, reaching 678.98 and 588.09 g plant $^{-1}$, respectively, while the best results of yield were observed at soil water tension of 15 $\mathrm{kPa}$ and nitrogen dose of $260.25 \mathrm{~kg} \mathrm{ha}^{-1}$, which led to values of 56.98 and $55.27 \mathrm{tha}^{-1}$, respectively.

Maximum water use efficiency was obtained at nitrogen dose of $239.16 \mathrm{~kg} \mathrm{ha}^{-1}\left(98.28 \mathrm{~kg} \mathrm{~mm}^{-1}\right)$ and tension of $15 \mathrm{kPa}\left(113.16 \mathrm{~kg} \mathrm{~mm}^{-1}\right)$.

Maximum nitrogen use efficiency (420.47 $\mathrm{kg} \mathrm{kg}^{-1}$ ) was obtained with the combination between tension of $15 \mathrm{kPa}$ and nitrogen dose of 135 $\mathrm{kg} \mathrm{ha}^{-1}$

Therefore, in view of the obtained results, soil water tension of $15 \mathrm{kPa}$ and nitrogen dose of $265 \mathrm{~kg}$ $\mathrm{ha}^{-1}$ are recommended for bell pepper cultivation in protected environment.

\section{ACKNOWLEDGMENTS}

We thank the Coordination for the Improvement of Higher Education Personnel (CAPES) for granting the Master's Scholarship and the Federal Rural University of the Amazon for the aid in the publication of this study. 


\section{REFERENCES}

ALBUQUERQUE, F. S. et al. Nutrientes minerais em pimentão fertirrigado sob lâminas de irrigação e doses de potássio. Horticultura Brasileira, 30: 681$687,2012$.

ARAGÃO, V. F. et al. Produção e eficiência no uso de água do pimentão submetido a diferentes lâminas de irrigação e níveis de nitrogênio. Revista Brasileira de Agricultura Irrigada, 6: 207-216, 2012.

BRASIL. IBGE. Censo Agropecuário, 2006. Rio de Janeiro, p. 1-777, 2006.

CABELLO, F. P. Riegos localizados de alta frecuencia (RLAF) goteo, microaspersión, exudasión. $3^{\text {a }}$ ed. Madrid: Mundi-Prensa, 1996. 511 p.

CANTUÁRIO, F. S. et al. Podridão apical e escaldadura em frutos de pimentão submetidos a estresse hídrico e doses de silício. Horticultura Brasileira, 32: 215-219, 2014.

CARVALHO, J. A. et al. Análise produtiva e econômica do pimentão-vermelho irrigado com diferentes lâminas, cultivado em ambiente protegido. Revista Brasileira de Engenharia Agrícola e Ambiental, 15: 569-574, 2011.

CARVALHO, J. A. et al. Pimentão cultivado em ambiente protegido sob diferentes tensões de água no solo. Engenharia na Agricultura, 23: 236-245, 2016.

CARVALHO, K. S. et al. Cultivo de pimentão vermelho submetido a tensões de água no solo. Enciclopédia Biosfera, 9: 659-669, 2013.

DOORENBOS, J.; KASSAM, A. H. Efeito da água no rendimento das culturas. Tradução: GHEYI, $H$. R. et al. Campina Grande: UFPB, 1994. 306 p. (Estudos FAO: Irrigação e drenagem, 33).

FILGUEIRA, F. A. R. Novo manual de olericultura: Agrotecnologia moderna na produção e comercialização de hortaliças. 3. ed. Viçosa, MG: UFV, 2008. 242 p.

GOTO, R.; TIVELLI, S. W. Produção de hortaliças em ambiente protegido: condições subtropicais. 1 . ed. São Paulo, SP: UNESP, 1998. 319 p.

HF BRASIL/CEPEA. Hortifruti Brasil. Principais características do pimentão. Disponível em: <https: //www.hfbrasil.org.br/br/hortifruticepeaprincipais-caracteristicas-do-pimentao-no-br.aspx $>$ Acesso em: 01 dez. 2018.
LIMA JUNIOR, J. A. et al. Efeito da irrigação sobre o rendimento produtivo da alface americana, em cultivo protegido. Revista Brasileira de Engenharia Agrícola e Ambiental, 14: 797-803, 2010 .

LORENZONI, M. Z. et al. Produção de pimentão fertirrigado sob diferentes níveis de nitrogênio e potássio em ambiente protegido. In: IX Encontro Internacional de produção científica - EPCC, 2015, Maringá. Anais... Maringá: UniCesumar, 2015. n. 9, p. 4-8.

LOSS, J. B. Desenvolvimento vegetativo e produtivo do pimentão submetido a tensões de água no solo. 2017. 57 f. Dissertação (Mestrado em Produção vegetal: Área de concentração Recursos hídricos e geoprocessamento em sistemas agrícolas) - Universidade Federal do Espírito Santo, Porto Alegre, 2017.

MANTOVANI, E. C. Avalia: Programa de avaliação da irrigação por aspersão e localizada. Viçosa, MG: UFV, 2001.

MAROUELLI, W. A.; SILVA, W. L. C. Irrigação na cultura do pimentão. 1. ed. Brasília, DF: EMBRAPA HORTALIÇAS, 2012. 19 p. (Circular técnica, 101).

MAROUELLI, W. A.; SILVA, W. L. C. Irrigação e fertirrigação na cultura do pimentão. In: SOUSA, V. F.; MAROUELLI, W. A. et al. (Eds.). Irrigação e fertirrigação em fruteiras e hortaliças. Brasília, DF: Embrapa , 2014. cap. 25, p. 697-714.

MAROUELLI, W. A. Tensiômetros para o controle de irrigação em hortaliças. 1. ed. Brasília, DF: EMBRAPA HORTALIÇAS, 2008. 15 p. (Circular técnica, 57).

MONTEIRO, R. O. C. et al. Eficiência no uso da água e nitrogênio na produção de melão. Irriga, 13: 367-377, 2008

OLIVEIRA, F. A. et al. Nutrição mineral de plantas submetido a diferentes manejos de fertirrigação. Revista Horticultura Brasileira, 33: 216-223, 2015

PINTO, C. M. F. et al. Pimentão. In: PAULA JUNIOR, T. J.; VENZON, M. (Eds.). 101 culturas: Manual de tecnologia agrícola. Minas Gerais, BH: Epamig, 2007. cap. 83, p. 641-650.

RINCÓN, L. et al. Crecimiento y absorción de nutrientes del pimiento grueso bajo invernadero. Investigación Agraria, 10: 47-59, 1995.

ROCHA, P. A. Produção de pimentão sob 
diferentes estratégias de irrigação com e sem cobertura do solo, no semiárido Baiano. 2017. 58 f. Dissertação (Mestrado Profissional: Área de concentração Produção vegetal) - Instituto Federal de Educação, Ciência e Tecnologia Baiano, Guanambi, 2017.

SEZEN, M. S. et al. Yield and quality response of drip-irrigated pepper under Mediterranean climate conditions to various water regimes. African Journal of Biotechnology, 10: 1329-1339, 2011.

TODESCHINI, M. H. et al. Eficiência de uso do nitrogênio em cultivares modernas de trigo. Bragantia, 75: 351-361, 2016.

VAN GENUCHTEN, M. Th. A closed-form equation for predicting the hydraulic conductivity of unsaturated soils. Soil Science Society of America Journal, 44: 892-898, 1980. 